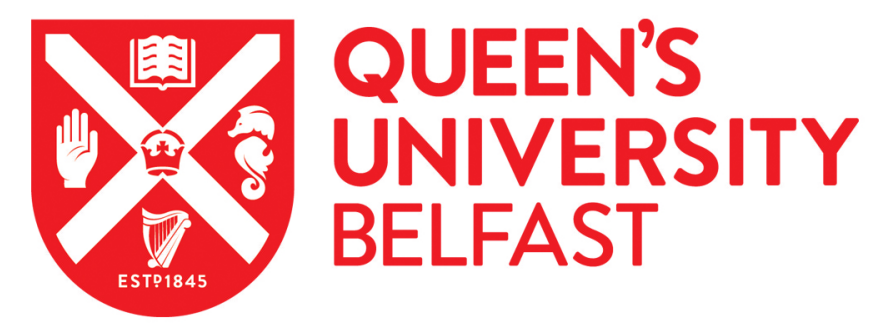

\title{
Effectiveness of BFRP confinement on the compressive behaviour of clay brick masonry cylinders
}

D'Anna, J., Amato, G., Chen, J-F., Minafò, G., \& La Mendola, L. (2020). Effectiveness of BFRP confinement on the compressive behaviour of clay brick masonry cylinders. Composite Structures, 249, [112558].

https://doi.org/10.1016/j.compstruct.2020.112558

\section{Published in:}

Composite Structures

Document Version:

Peer reviewed version

Queen's University Belfast - Research Portal:

Link to publication record in Queen's University Belfast Research Portal

\section{Publisher rights}

Copyright 2020 Elsevier

This manuscript is distributed under a Creative Commons Attribution-NonCommercial-NoDerivs License

(https://creativecommons.org/licenses/by-nc-nd/4.0/), which permits distribution and reproduction for non-commercial purposes, provided the author and source are cited.

\section{General rights}

Copyright for the publications made accessible via the Queen's University Belfast Research Portal is retained by the author(s) and / or other copyright owners and it is a condition of accessing these publications that users recognise and abide by the legal requirements associated with these rights.

Take down policy

The Research Portal is Queen's institutional repository that provides access to Queen's research output. Every effort has been made to ensure that content in the Research Portal does not infringe any person's rights, or applicable UK laws. If you discover content in the Research Portal that you believe breaches copyright or violates any law, please contact openaccess@qub.ac.uk. 


\section{Effectiveness of BFRP confinement on the compressive behaviour of clay brick} masonry cylinders

Jennifer D'Anna*1, Giuseppina Amato ${ }^{2}$, Jian-Fei Chen ${ }^{3}$, Giovanni Minafò ${ }^{1}$, Lidia La Mendola ${ }^{1}$

${ }^{1}$ Università degli Studi di Palermo, Dipartimento di Ingegneria, Viale delle Scienze, 90128 Palermo (Italy).

2 School of Natural and Built Environment, David Keir Building, Queen's University Belfast (UK)

${ }^{3}$ Department of Ocean Science and Engineering, Southern University of Science and Technology (China)

\section{Abstract}

This paper presents the results of an experimental and analytical study on the compressive behaviour of small clay brick masonry cylinders reinforced with a basalt fibre reinforced polymer (BFRP) composite. Fourteen cylinders, manufactured using two assembling schemes and confined using either one or two layers of BFRP grids, were tested under monotonic compression loading. Traditional strain measuring systems were integrated with digital image correlation (DIC) technique. The BFRP confined masonry cylinders showed a ductile behaviour characterised by a softening branch of the stress-strain curve. The experimental strains, strength, and full stressstrain curves were modelled using analytical models available in the literature. A modified version of the CNR model proposed in this study provided the best strength prediction.

Keywords: masonry, BFRP, confinement, cylinders, digital image correlation

\section{Introduction}

Improving the axial capacity and ductility of masonry columns using passive confinement induced by wraps of fibre reinforced polymers (FRP) has become a common engineering practice. The method is based on the high tensile strength of composites and consequent high confinement pressure achievable. Several experimental and theoretical studies were carried out in the past 20 years to study the confinement effect due to carbon and glass fibre composites on the compressive behaviour of masonry. More recently basalt fibres have gained increasing attention as FRP reinforcement material for strengthening applications, especially as an alternative to glass fibres. Basalt is a natural volcanic rock originating at a depth of hundreds of kilometres beneath the earth's crust and reaching the surface as molten magma [1]. Basalt fibres are produced with a manufacturing process which is similar to that adopted for manufacturing glass fibres. The main difference is that glass is produced from a complex batch of materials, while basalt is a naturally occurring rock which just needs to be molten to produce a filament and then fibres. The simplicity 
of this manufacturing process reduces the production cost and the amount of energy compared to glass fibres, with several benefits in terms of environmental impact. Moreover, basalt is a natural occurring rock, which makes it particularly suitable for applications in masonry structures. However, the quality and the chemical composition of the raw material can significantly influence the cost and properties of the fibres and can lead to variability of the mechanical properties of the material [1].

Despite the many studies on columns wrapped with carbon and glass FRPs (CFRP and GFRP respectively), there is very limited experimental data on BFRP-wrapped columns, and most studies investigated concrete members. Campione et al. [2] studied the application of a bidirectional basalt fabric with epoxy resin to concrete cylinders by axial compression tests. The specimens confined with BFRP exhibited strain-softening behaviour after the peak load with negligible strength increases but a good enhancement of ultimate strain, up to five times the peak strain of the unconfined specimens. More recently, Ouyang et al. [3] presented a comparative study of the seismic behaviour of reinforced concrete square columns retrofitted with CFRP and BFRP sheets. The study demonstrated that the BFRP composites are a promising alternative to conventional FRPs (e.g., CFRPs) for retrofitting square RC columns. Sadeghian and Fillmore [4] studied the distribution of hoop strains along the surface of concrete cylinders confined by two, four or six layers of BFRP. They found that the failure of all specimens wrapped with BFRPs was controlled by the rupture of the composite along the hoop direction in the non-overlap region; in comparison with similar studies on CFRP, a less explosive failure of BFRP-wrapped cylinders was observed; moreover, the number of layers had a negligible effect on the hoop strain distribution.

Huang et al. [5] studied the compressive behaviour of concrete columns confined by different basalt fibre-reinforced polymers. The test results showed that the compressive strengths of confined specimens increased by $20 \%-71 \%$ for circular columns, while the ultimate strains improved by $49 \%-296 \%$. Both the strength and the ultimate strain of confined concrete improved with increasing number of BFRP layers.

Baasankhuu et al. [6] investigated the confinement effect of BFRP wrapping applied on concrete cylinders. Different number of FRP layers was investigated. Confinement by BFRP was effective, as underlined by the continuously ascending stress-strain relationship of the confined concrete. The compressive strength of specimens confined by $2-6$ layers of BFRP was 1.4-2.5 times that of the unconfined concrete.

Suon et al. [7] presented an experimental study on the compressive behaviour of BFRP-confined small-scale concrete specimens. Different parameters were investigated, such as cross-section shape and number of BFRP layers. The 
results showed the ability of basalt fibre in improving the concrete compressive behaviour. In particular, it was shown that the ultimate condition of confined concrete enhances with the increase of BFRP layers.

Regarding masonry members retrofitted with BFRP, Di Ludovico et al. [8] presented the results of an experimental investigation on the compressive behaviour of tuff or clay-brick masonry columns confined with carbon, glass and basalt FRP. For clay brick masonry columns, the study found that GFRP and BFRP confining systems led to similar compressive strength gain (about 57\%), but BFRP wrapping produced a higher ultimate axial strain gain ( $413 \%$ for BFRP against 259\% for GFRP) even if the mechanical external reinforcement ratio was lower than in case of GRFP.

Micelli et al. [9] investigated the mechanical behaviour of circular masonry columns in compression confined with glass and basalt FRP and FRCM (fibre reinforced cementitious mortar) unidirectional sheets and grids applied in a continuous or discontinuous way along the column. They also studied the effect of active confinement using a GFRP and shape memory alloys (SMA) system. These tests highlighted the effectiveness of the FRP confinement; in particular, the unidirectional basalt and glass sheet wraps produced the highest values of strength and ductility, with failure due to the fibre rupture. Discontinuous wraps produced a significant upgrade of the mechanical properties and discontinuous wrapping with basalt grid produced higher mechanical properties of the confined masonry respect to the other cases with higher FRP amount.

Regarding the modeling of FRP confined masonry columns, one of the first studies was carried out by Krevaikas and Triantafillou (2005) [10] who tested 42 clay brick masonry columns confined with glass and Carbon FRP and formulated a simple model for calculating both the strength and ultimate strain gain. Corradi et al. 11 (2007) [11] adapted the stress-strain law proposed by Campione and Miraglia (2003) [12] for concrete elements to model the compressive behaviour of Carbon FRP-confined masonry. Di Ludovico et al. (2010) [8] , based on their experimental investigation on tuff or clay-brick masonry columns confined by carbon, glass and basalt FRPs, proposed new expressions for evaluating the strength enhancement in masonry columns strengthened by FRP systems. Faella et al. (2011) [13] analysed a wide experimental database of published studies to assess how models available for FRPconfined concrete columns perform when adapted to masonry members. They showed that the available models often provide inaccurate estimations, due to the fact that they were calibrated on specific types of masonry. They also calibrated some analytical formulations considering a variable number of parameters.

More recently, Lignola et al. (2014) [14] summarized previous studies in the literature and proposed a theoretical approach based on the Mohr-Coulomb strength criterion for determining the strength increase due to FRP 
confinement. Additionally, the CNR-DT 200/2013 Guidelines [15], the Italian reference standard for upgrading interventions on concrete and masonry structure using FRP, also provides a model for the confined strength of FRPconfined masonry columns.

A comparative analysis of the main theoretical models was carried out by Minafo et al. (2017) [16] to estimate increased strength, ultimate strain and full stress-strain curves of FRP confined masonry in compression based on available experimental data. They considered a number of geometrical and mechanical variables, included the influence of the section corner radius. They concluded that the confined strength model proposed by the current Italian CNR DT 200 (2013) guidelines [15] is quite conservative, while the model proposed by Di Ludovico et al. (2010) [8] is the most reliable. This summary shows that the experimental studies carried out on columns confined by BFRP wraps are still insufficient to calibrate existing models and design formulations either covering glass, carbon and basalt FRP or specifically formulated for BFRP composites. Moreover, very few experimental studies on FRP-strengthened masonry columns focus circular columns [17-19].

In this study, in order to investigate the effect of pure confinement, masonry specimens with circular cross section were tested. As the absence of corners in the circular section allows avoiding stress concentration in the external wrap and, in these specimens the strengthening system can reach, in principle, its maximum stress in a uniform manner [20, 21]. However, it should be noted that the circumferential rupture strain in the FRP wrap is much smaller than the coupon test failure strain due to various factors including geometrical discontinuities at the ends of the composite. Moreover, the obtained strength increase can be considered as an upper bound of the confinement effect for real case studies. This paper presents the results of an experimental investigation carried out on fourteen small scale brick masonry cylinders confined by BFRP wraps and subjected to uniaxial compression. The test programme included two variables were: the effect of the vertical mortar joints of two different assembly schemes and the number of BFRP layers used for confinement purposes. Strains obtained by traditional measuring instruments were compared with those obtained with the Digital Image Correlation (DIC) technique. The experimental results including confined strength, ultimate strain and full stress-strain curves, were compared to predictions obtained using available models in the literature, and those from a modified versions of the CNR model [15] and Krevaikas and Triantafillou's model [10]. 
Fourteen small clay brick cylinders were tested under axial compressive loading in this study. The cylinders, with a diameter of $94 \mathrm{~mm}$ and height of $190 \mathrm{~mm}$, were obtained by coring two different assembly schemes (Schemes I and II)

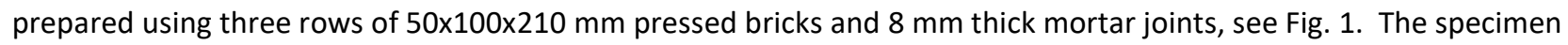
shape and size were selected to assess the effect of uniform confinement on masonry, at material level, under compressive stress. Cylinders cored from Scheme I had only one vertical joint in the middle third while cylinders cored from Scheme II had three staggered vertical joints, one at each level. The cylinders were cored with a laboratorycoring machine after 30 days of curing and then wrapped with one or two layers of basalt FRP composite as listed in

Table 1. It should be considered that the same number of specimens was planned to be tested for both schemes, however some cylinders were damaged during the coring or the preparation operations. For this reason, the number of control specimens was different for the two schemes. The cylinders were labelled as Cn_XYL where C represents "cylinder", $\mathrm{n}$ indicates the specimen number, $\mathrm{X}$ identifies the assembly scheme (W for Scheme I, C for Scheme II), Y indicates the number of confinement layers ( 1 and 2 for one or two layers respectively), $L$ means "layer". In the case of unconfined cylinders, the last two letters were replaced by "Un" (unconfined).

Table 1: Test specimens

\begin{tabular}{l|l|l}
\hline Assembly scheme & Specimen & Number of BFRP layers \\
\hline \multirow{4}{*}{$\begin{array}{l}\text { Scheme I } \\
\text { (n.1 vertical joint) }\end{array}$} & $\begin{array}{l}\text { C1_WUn } \\
\text { C2_WUn } \\
\text { C3_WUn } \\
\text { C4_WUn }\end{array}$ & 0 \\
\cline { 2 - 3 } & $\begin{array}{l}\text { C1R_W1L } \\
\text { C2R_W1L }\end{array}$ & 1 \\
\cline { 2 - 3 } & $\begin{array}{l}\text { C1R_W2L } \\
\text { C2R_W2L }\end{array}$ & 2 \\
\hline \multirow{5}{*}{$\begin{array}{l}\text { Scheme II } \\
\text { (n.2 vertical joints) }\end{array}$} & $\begin{array}{l}\text { C1_CUn } \\
\text { C2_CUn }\end{array}$ & 0 \\
\cline { 2 - 3 } & $\begin{array}{l}\text { C1R_C1L } \\
\text { C2R_C1L }\end{array}$ & 1 \\
\cline { 2 - 3 } & $\begin{array}{l}\text { C1R_C2L } \\
\text { C2R_C2L }\end{array}$ & 2 \\
\hline
\end{tabular}



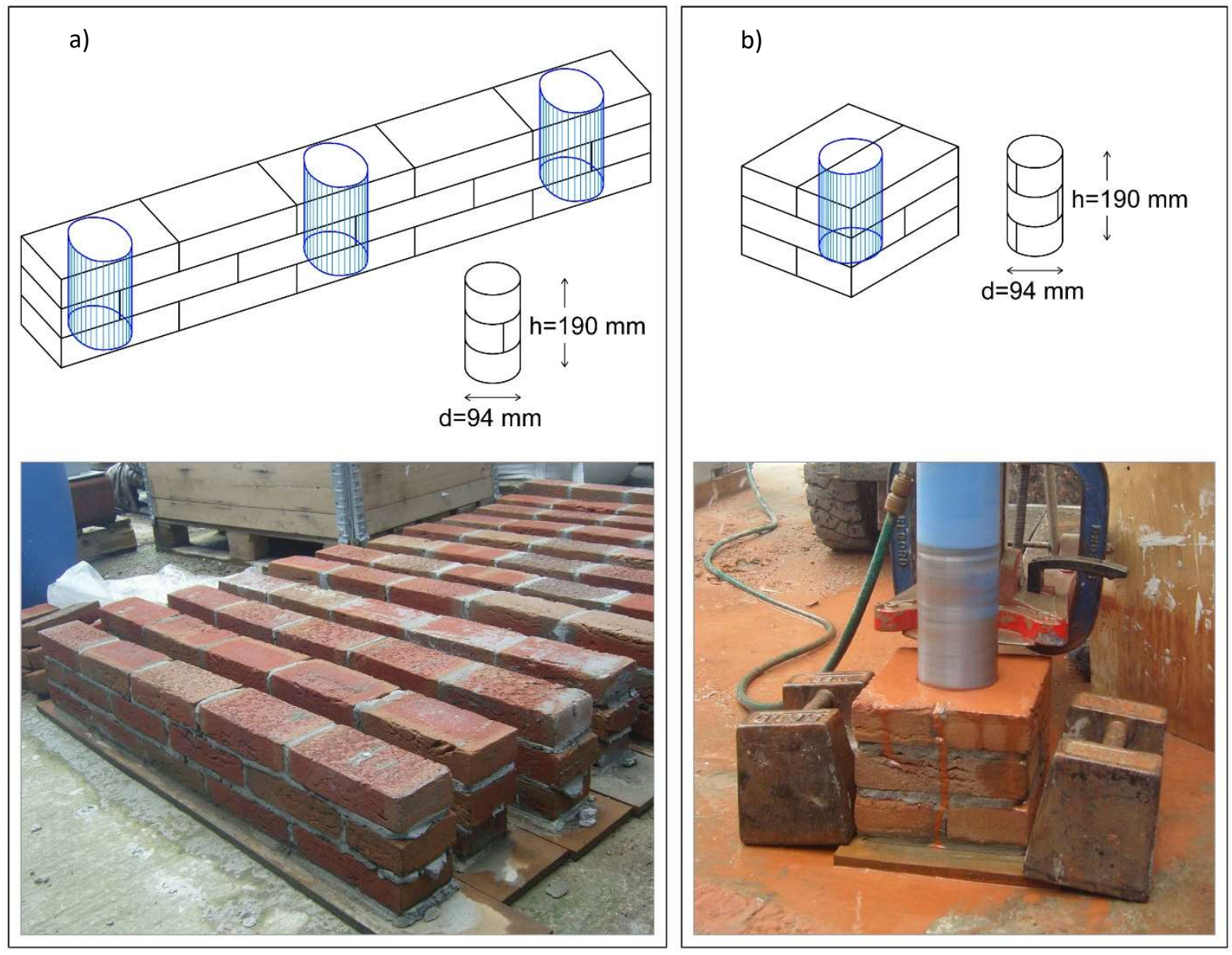

129

Fig. 1 Brick assembly schemes: a) Scheme I; b) Scheme II

\section{Materials}

The bricks and mortar used for the masonry cylinders were tested according to EN 772-1 [22] and EN 1015-11 [23].

The bricks had a compressive strength equal to $42.53 \mathrm{MPa}$. The mortar (cement/sand weight ratio of $1 / 5$ ) had compressive strength equal to $20.93 \mathrm{MPa}$ and tensile strength equal to $5.33 \mathrm{MPa}$.

A bidirectional primed alkali-resistant basalt fibre grid with cell size of $6 \times 6 \mathrm{~mm}$ and two-component epoxy resin were used for the BFRP wraps. The grid and epoxy resin geometrical and mechanical characteristics provided by the supplier are reported on Table 2. 
Table 2: Properties of BFRP components (supplier data)

\begin{tabular}{llllllll}
\hline Material & $\begin{array}{l}\text { Unit } \\
\text { weight }\end{array}$ & Mesh size & Density & $\begin{array}{l}\text { Tensile } \\
\text { strength }\end{array}$ & $\begin{array}{l}\text { Elastic } \\
\text { modulus }\end{array}$ & $\begin{array}{l}\text { Equivalent } \\
\text { thickness }\end{array}$ & $\begin{array}{l}\text { Elongation at } \\
\text { failure }\end{array}$ \\
\hline Basalt grid & $250 \mathrm{~g} / \mathrm{m}^{2}$ & $6 \times 6 \mathrm{~mm}$ & $2.75 \mathrm{~g} / \mathrm{cm}^{3}$ & $60 \mathrm{kN} / \mathrm{m}$ & $89 \mathrm{GPa}$ & $0.039 \mathrm{~mm}$ & $1.8 \%$ \\
\hline $\begin{array}{l}\text { Epoxy } \\
\text { resin }\end{array}$ & - & - & - & $40 \mathrm{MPa}$ & $2.6 \mathrm{GPa}$ & - & - \\
\hline
\end{tabular}

The basalt grid was also tested in tension: twelve specimens in the warp and twelve in the weft direction, from the

same roll used for wrapping the cylinders, were prepared and tested according to ISO 13934-1 [24]. The grid was cut

in strips of $260 \times 13.5 \mathrm{~mm}^{2}$ and aluminium tabs were glued on the strip edges. Tests were conducted in displacement control using a Zwick-Roell universal machine, with a loading rate of $1 \mathrm{~mm} / \mathrm{min}$. The specimens were lighted up with a retro-light and displacements were recorded using a video-extensometer to track linear targets over a gauge length of $80 \mathrm{~mm}$. The test setup is shown in Fig. 2 together with a grid sample at failure.

The monotonic compressive tests on the cylinders were carried out using a $600 \mathrm{kN}$ electro-hydraulic loading frame. monotonic loading up to failure under displacement control at a rate of $0.12 \mathrm{~mm} / \mathrm{min}$.
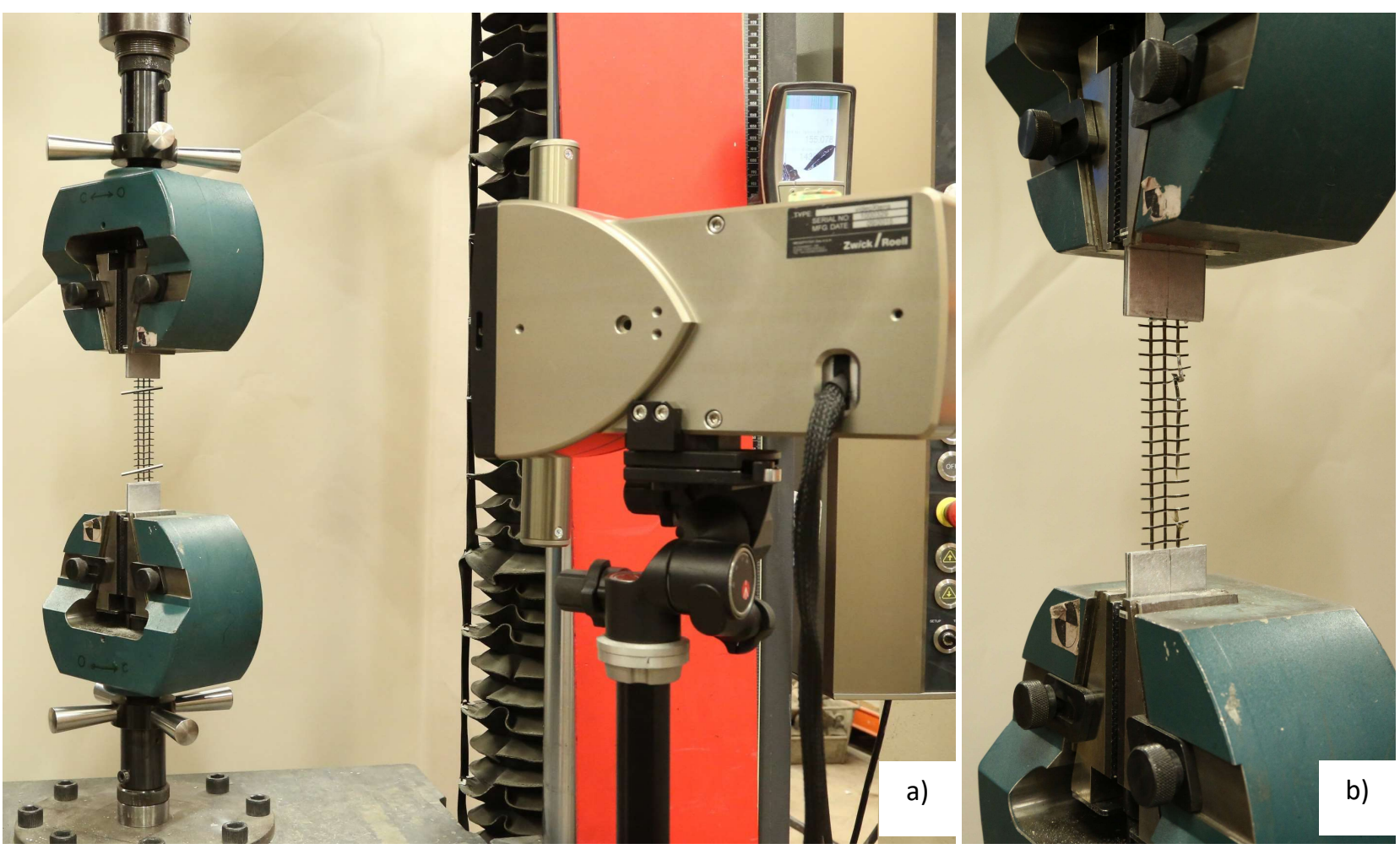

Fig. 2 Test on basalt grid samples: a) test setup; b) specimen at failure 


\section{Test set-up and instrumentation}

153 The cylinder test setup is shown in Fig. 3. A hydraulic jack connected to a manually controlled motor pump was used

154 to apply the axial compression force on the cylinders. The load was measured by a load cell attached to the loading

155 cylinder and recorded by a data acquisition system. A steel spherical head was placed above the upper bearing plate 156 to maintain a uniform distribution of axial stress and avoid load eccentricity.

157 Six linear voltage differential transducers (LVDTs) were installed, four on the upper loading platen and two on the

158 lower platen. Three extensometers connected to two steel rings placed around the specimens were also used to measure the local deformation in the middle half of the specimens, see Fig. $3 a$ and $b$.

Additionally, the strain field on the surface of the specimens was obtained from Digital Image Correlation (DIC) measurements using GOM Correlate [25]. A 22.3 Megapixel camera was used to capture images of the cylinders every four seconds using a remote trigger with a resolution of $16 \mathrm{pixel} / \mathrm{mm}$ and an average $4-5 \mathrm{pixel} / \mathrm{speckle.} \mathrm{The} \mathrm{specimens}$ were lighted up using two symmetrical white lights, able to provide a uniform light intensity on the front side of the samples (Fig. 3a). Strains were measured over a rectangular area of about 50x90 mm as shown in Fig. 4, as in [26]. Axial strains were computed as the average of 20 virtual strain gauges with a gauge length of $90 \mathrm{~mm}$. In the same way, hoop strains were measured as the average of 45 virtual strain gauges with a gauge length of $50 \mathrm{~mm}$. 


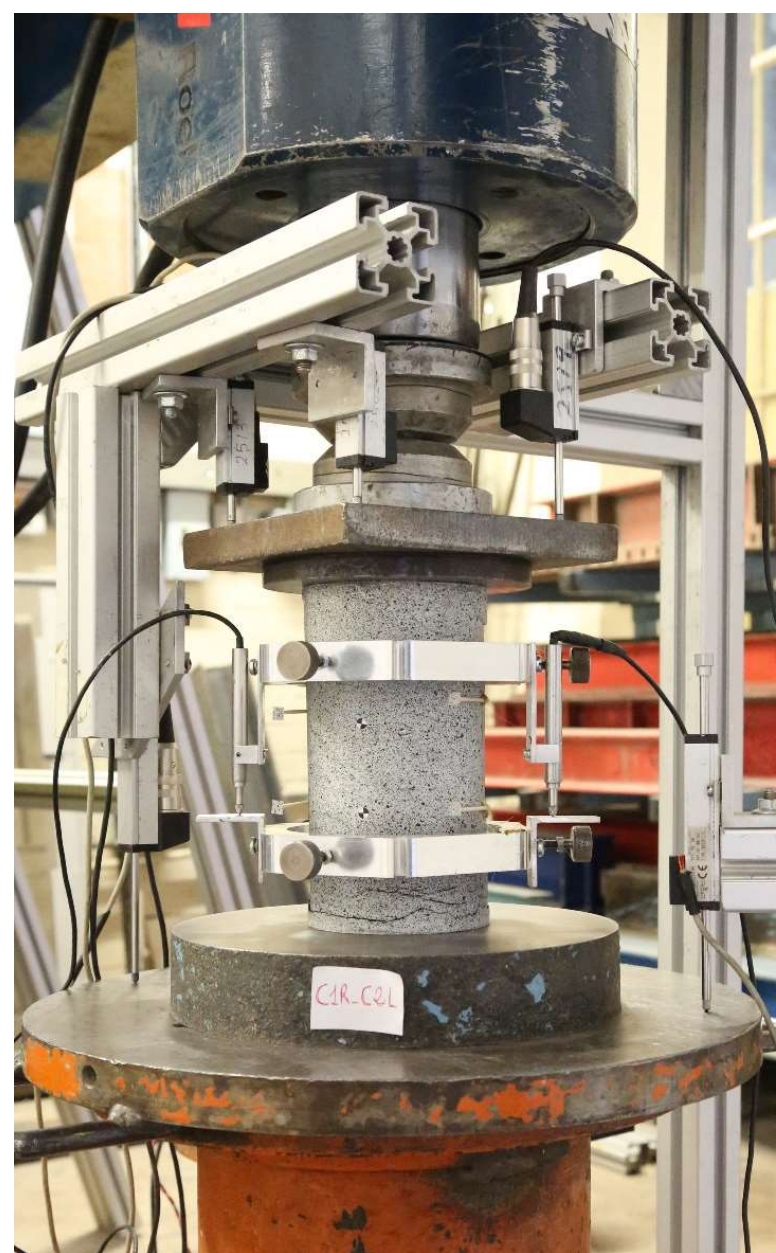

b)

a)
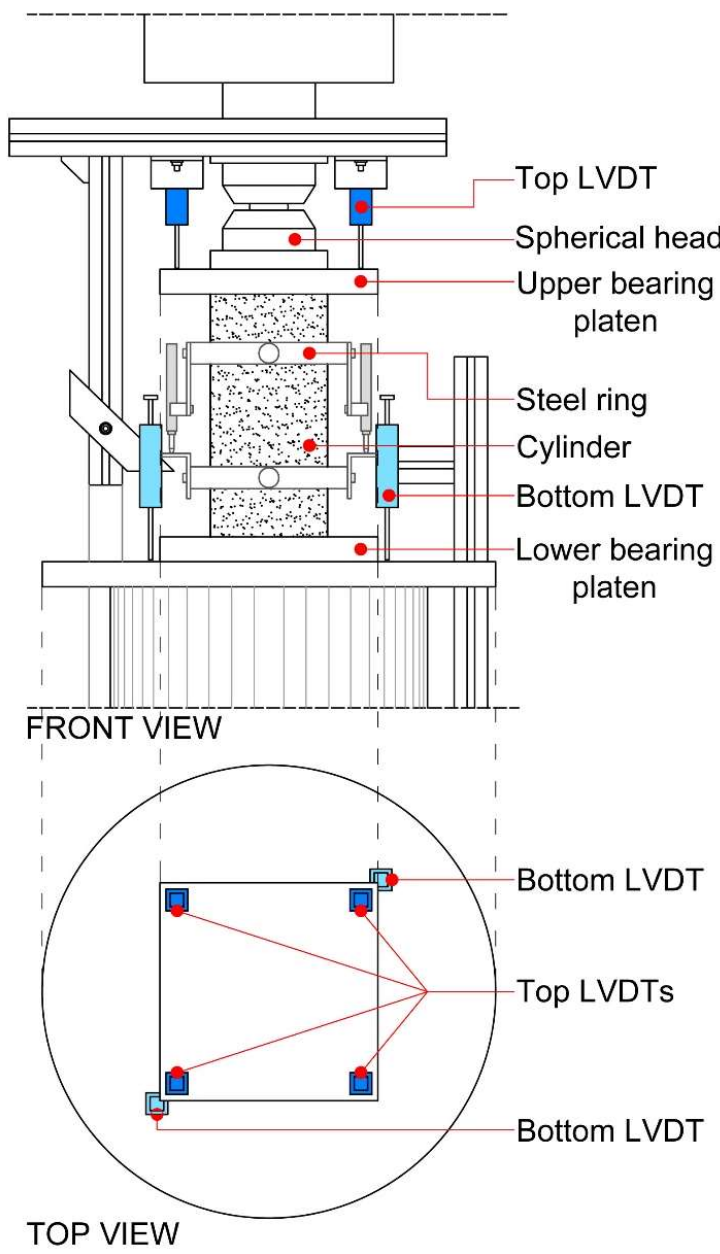

a)

Fig. 3 Cylinder compressive test: a) cylinder before testing; b) setup scheme

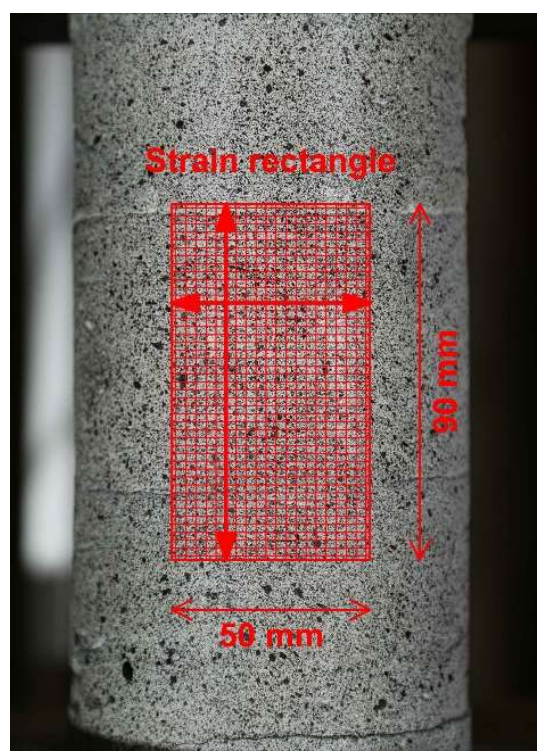

Fig. 4 Rectangular area used to calculate hoop and axial strains (DIC) 


\section{Basalt grid}

The experimental stress-strain curves for the basalt grid strip specimens are plotted in Fig. 5 . The grid was tested along both warp direction (the circumferential direction when wrapped on the cylinders), and weft direction (the vertical direction). As the textile has a discrete distribution of fibres (nominal cell size $6 \mathrm{~mm}$ ), the stress values in the graph were obtained considering the effective width corresponding to the number of yarns in the strip ( 2 cells and 3 yarns, therefore width=yarn $x$ cell size) and the equivalent grid thickness $(0.039 \mathrm{~mm})$.

Clearly, the tensile curves exhibited an almost linear elastic brittle behaviour. The average peak stress and strain, averaged over twelve samples tested along the warp direction, were $2045 \mathrm{MPa}$ and $2.6 \%$ respectively. The experimental average elastic modulus was $82 \mathrm{GPa}$ (Table 3). The values obtained from the specimens tested along the weft direction were $1983 \mathrm{MPa}, 2.4 \%$ and $82 \mathrm{GPa}$ respectively for the average strength, strain and Young's modulus.

Table 3: Results of basalt grid tests

\begin{tabular}{lllll}
\hline \multirow{2}{*}{ Mechanical property } & WARP DIRECTION & \multicolumn{3}{l}{ WEFT DIRECTION } \\
\cline { 2 - 5 } & Average & COV & Average & COV \\
\hline Tensile strength & $2045 \mathrm{MPa}$ & $10.55 \%$ & $1983 \mathrm{MPa}$ & $7.80 \%$ \\
\hline Young's modulus & $81.91 \mathrm{GPa}$ & $3.48 \%$ & $81.88 \mathrm{GPa}$ & $4.60 \%$ \\
\hline Ultimate tensile strain & $2.55 \%$ & $8.21 \%$ & $2.40 \%$ & $12.05 \%$ \\
\hline
\end{tabular}
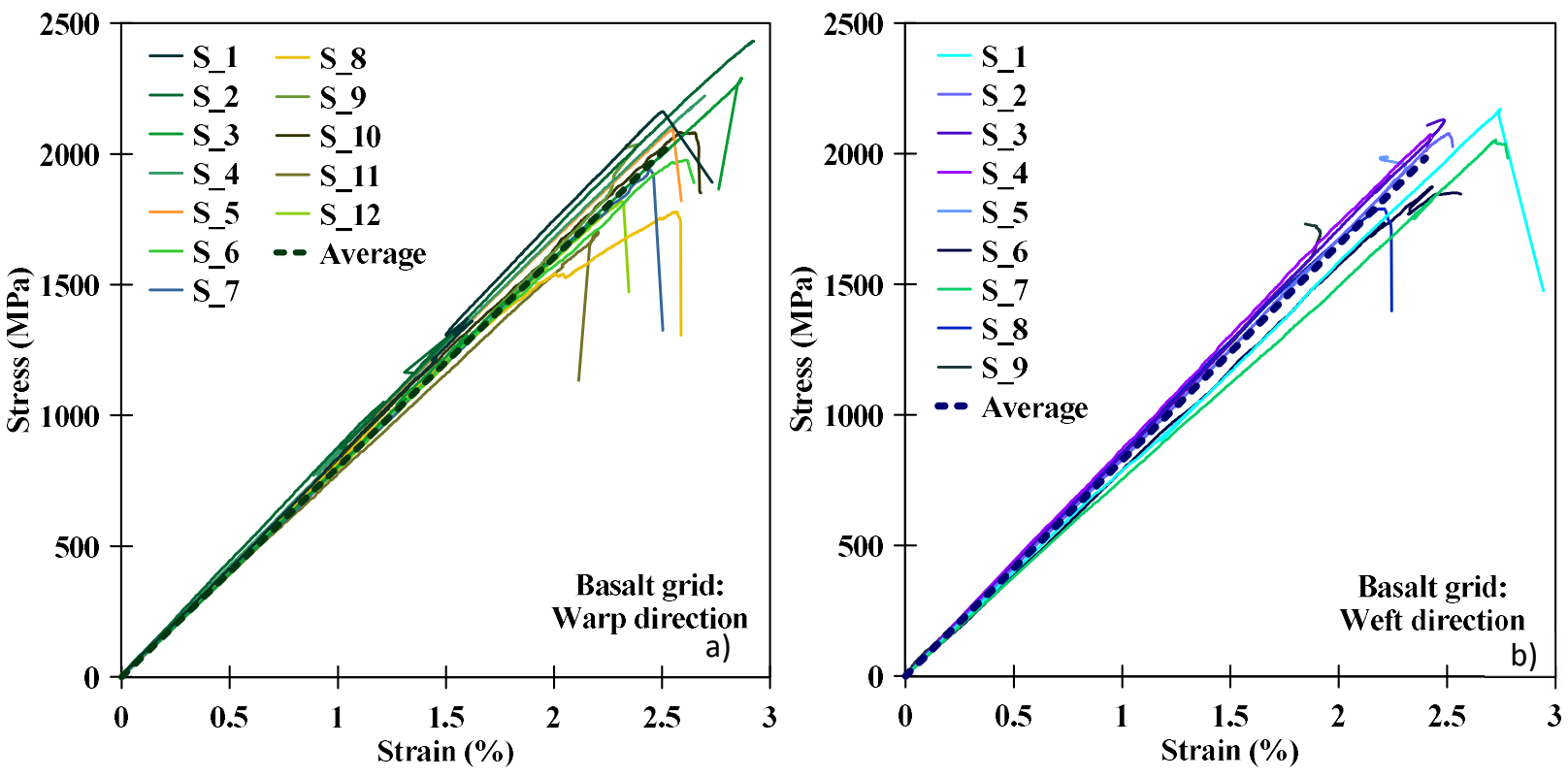

Fig. 5 Tensile tests of basalt grid strips: a) warp direction; b) weft direction 


\section{BFRP confined cylinders}

The axial stress-strain curves of Schemes I and II specimens obtained using LVDTs and transducers are plotted in Fig.

$6 a$ and $b$. The strain up to the peak was calculated using the displacement recorded over the central half height of the cylinders, while for the softening branch the LVDT measurements from the top and bottom plate were used as the ring fixed on the cylinders had to be taken off during the last part of the compression test. For unconfined cylinders C1_WUn, C2_WUn, and C3_WUn, the strain was calculated using the LVDTs on the top and bottom plates as the readings in the central area of the cylinders were lost due to technical problems. This explains the apparent lower stiffness measured for these specimens in Fig. 6 . The strains of these cylinders were not used for the calculating the average strain.

The stress-strain curves of the unconfined cylinders showed a brittle behaviour with an almost linear trend up to the peak followed by a sudden load drop after the peak, see Fig. 6 . The confined specimens also have an almost linear ascending branch up to about $80 \%$ of the peak stress, followed by an irregular softening curve with some stress drops.

Scheme II specimens showed a less steep softening branch than Scheme I specimens, indicating the higher influence of the vertical mortar joints.
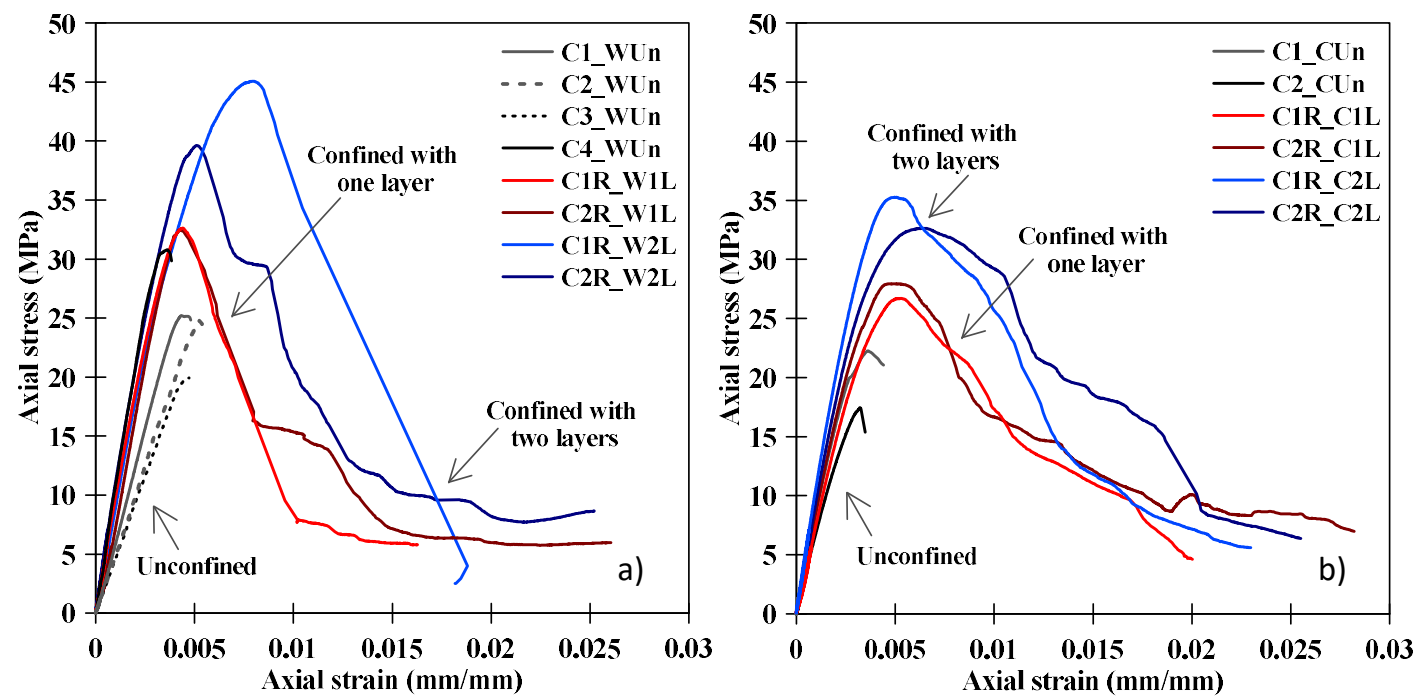

Fig. 6 Stress-strain curves of cylinders (LVDT readings): a) Scheme I; b) Scheme II.

The individual and average experimental results of cylinders are reported on Table 4 and Table 5. The tables contain: peak axial stress; peak and ultimate axial strains from LVDT/transducer readings; peak axial and hoop strains from DIC. The ultimate axial strain is calculated as the strain corresponding to a $15 \%$ stress reduction from the peak stress. For 
Table 4: Cylinder individual results

\begin{tabular}{|c|c|c|c|c|c|c|c|}
\hline & \multirow{3}{*}{ Specimen } & \multirow{3}{*}{$\begin{array}{l}\text { BFRP } \\
\text { layers }\end{array}$} & \multirow[b]{2}{*}{$\begin{array}{l}\text { Peak axial } \\
\text { stress } \\
\text { (MPa) }\end{array}$} & \multicolumn{2}{|c|}{ LVDTs/Transducers } & \multicolumn{2}{|l|}{ DIC } \\
\hline & & & & $\begin{array}{l}\text { Peak axial } \\
\text { strain } \\
(\mathrm{mm} / \mathrm{mm})\end{array}$ & $\begin{array}{l}\text { Ultimate axial } \\
\text { strain } \\
(\mathrm{mm} / \mathrm{mm})\end{array}$ & $\begin{array}{l}\text { Peak axial } \\
\text { strain } \\
(\mathrm{mm} / \mathrm{mm})\end{array}$ & $\begin{array}{l}\text { Peak hoop } \\
\text { strain } \\
(\mathrm{mm} / \mathrm{mm})\end{array}$ \\
\hline \multirow{8}{*}{ 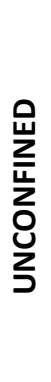 } & & & $f_{m 0}$ & $\varepsilon_{\mathrm{m} 0}$ & $\varepsilon_{\mathrm{m} 0 \mathrm{u}}$ & $\varepsilon_{m 0}^{\prime}$ & $\varepsilon_{\mathrm{m} 0 \mathrm{~h}}$ \\
\hline & C1_WUn & - & 25.24 & $0.0043^{*}$ & $0.0048 * *$ & - & - \\
\hline & C2_WUn & - & 24.78 & $0.0052 *$ & $0.0054 *$ & 0.0028 & 0.0030 \\
\hline & C3_WUn & - & 19.95 & $0.0049 *$ & $0.0049 *$ & 0.0024 & 0.0029 \\
\hline & C4_WUn & - & 30.79 & 0.0036 & $0.0038 * *$ & - & - \\
\hline & C1_CUn & - & 22.25 & 0.0036 & 0.0042 & - & - \\
\hline & C2_CUn & - & 17.44 & 0.0032 & 0.0035 & - & - \\
\hline & & & $f_{m c}$ & $\varepsilon_{\mathrm{mc}}$ & $\varepsilon_{\text {mcu }}$ & $\varepsilon_{\mathrm{mc}}^{\prime}$ & $\varepsilon_{\text {mch }}$ \\
\hline \multirow{8}{*}{$\begin{array}{l}\text { 인 } \\
\text { 는 } \\
\text { 어 }\end{array}$} & C1_W1L & 1 & 32.64 & 0.0044 & 0.0057 & 0.0019 & 0.0020 \\
\hline & C2_W1L & 1 & 32.47 & 0.0040 & 0.0056 & 0.0037 & 0.0041 \\
\hline & C1_W2L & 2 & 45.08 & 0.0080 & 0.0092 & 0.0069 & 0.0064 \\
\hline & C2_W2L & 2 & 39.64 & 0.0051 & 0.0065 & 0.0045 & 0.0034 \\
\hline & C1_C1L & 1 & 26.71 & 0.0053 & 0.0075 & 0.0036 & 0.0044 \\
\hline & C2_C1L & 1 & 27.95 & 0.0049 & 0.0073 & 0.0053 & 0.0047 \\
\hline & C1_C2L & 2 & 35.26 & 0.0051 & 0.008 & 0.0031 & 0.0032 \\
\hline & C2_C2L & 2 & 32.64 & 0.0065 & 0.011 & 0.0052 & 0.0040 \\
\hline
\end{tabular}

212

two of the unconfined cylinders, the ultimate axial strain is the last detected value. Table 5 also provides the ratios between the confined and unconfined cylinder peak stress $\left(f_{m c} / f_{m 0}\right)$, the ratios between the confined and unconfined cylinder peak strain $\left(\varepsilon_{m c} / \varepsilon_{m 0}\right)$, and the ratios between hoop and axial strains for confined cylinders $\left(\varepsilon_{m c h} / \varepsilon^{\prime}{ }_{m c}\right)$.

*Value not used for calculation of average peak/ultimate strain. **Last detected deformation

The average peak stresses for the unconfined specimens were 25.19 MPa and 19.85 MPa for Scheme I and II specimens respectively, showing a significant detrimental effect of the vertical joints. In comparison with the unconfined specimens, one layer of BFRP composite enhanced the cylinder average strength by $29 \%$ and $38 \%$ respectively for Scheme I and II. For cylinders confined with two BFRP layers the average strength gain was $68 \%$ for Scheme I and 71\% for Scheme II, about the double than that with one layer. The strength increments are comparable to those achieved in other studies [5]. One layer of composite therefore had a larger confinement effect on the weakest masonry cylinders, while two layers produced similar strength increments.

Scheme I cylinders wrapped with one layer exhibited a small peak strain increase (17\%) while two layers of BFRP composite increased the peak strain by $82 \%$ compared to control specimens. For Scheme II cylinders confined with one and with two BFRP layers the average peak strains were $49 \%$ and $69 \%$ higher than for unconfined specimens. These increments are about proportional to the corresponding increments of strength. 


\begin{tabular}{|c|c|c|c|c|c|c|c|}
\hline \multirow{3}{*}{ Assembly } & \multirow{3}{*}{ Confinement } & \multicolumn{3}{|c|}{ LVDTs/Transducers } & \multicolumn{3}{|l|}{ DIC } \\
\hline & & $\begin{array}{l}\text { Peak axial } \\
\text { Stress } \\
(\mathrm{MPa})\end{array}$ & $\begin{array}{l}\text { Peak axial } \\
\text { strain } \\
(\mathrm{mm} / \mathrm{mm})\end{array}$ & $\begin{array}{l}\text { Ultimate axial } \\
\text { strain } \\
(\mathrm{mm} / \mathrm{mm})\end{array}$ & $\begin{array}{l}\text { Peak axial } \\
\text { strain } \\
(\mathrm{mm} / \mathrm{mm})\end{array}$ & $\begin{array}{l}\text { Peak hoop } \\
\text { strain } \\
(\mathrm{mm} / \mathrm{mm})\end{array}$ & \\
\hline & & $f_{m 0}$ & $\varepsilon_{\mathrm{m} 0}$ & $\varepsilon_{\mathrm{mu}}$ & $\varepsilon_{m 0}^{\prime}$ & $\varepsilon_{\mathrm{mOh}}$ & $\varepsilon_{\mathrm{m} 0 \mathrm{~h}} / \varepsilon_{\mathrm{m} 0}^{\prime}$ \\
\hline Scheme I & unconfined & 25.19 & 0.0036 & 0.0038 & 0.0026 & 0.0030 & 1.15 \\
\hline \multirow[t]{2}{*}{ Scheme II } & unconfined & 19.85 & 0.0034 & 0.0038 & / & / & / \\
\hline & & $f_{\mathrm{mc}}$ & $\varepsilon_{\mathrm{mc}}$ & $\varepsilon_{\mathrm{mcu}}$ & $\varepsilon_{\mathrm{mc}}^{\prime}$ & $\varepsilon_{\mathrm{mch}}$ & $\varepsilon_{\mathrm{mch}} / \varepsilon_{\mathrm{mc}}^{\prime}$ \\
\hline \multirow{2}{*}{ Scheme I } & 1 layer & 32.56 & 0.0042 & 0.0056 & 0.0028 & 0.0030 & 1.07 \\
\hline & 2 layers & 42.36 & 0.0065 & 0.0078 & 0.0057 & 0.0049 & 0.86 \\
\hline \multirow{2}{*}{ Scheme II } & 1 layer & 27.33 & 0.0051 & 0.0074 & 0.0045 & 0.0046 & 1.02 \\
\hline & 2 layers & 33.95 & 0.0058 & 0.0094 & 0.0042 & 0.0036 & 0.86 \\
\hline \multicolumn{8}{|c|}{ Confined to unconfined ratios } \\
\hline & & $\mathbf{f}_{\mathrm{mc}} / \mathbf{f}_{\mathrm{mo}}$ & $\varepsilon_{\mathrm{mc}} / \varepsilon_{\mathrm{m} 0}$ & $\varepsilon_{\mathrm{mcu}} / \varepsilon_{\mathrm{mc}}$ & $\varepsilon_{\mathrm{mc}}^{\prime} / \varepsilon_{\mathrm{m} 0}^{\prime}$ & $\varepsilon_{\mathrm{mch}} / \varepsilon_{\mathrm{m} 0 \mathrm{~h}}$ & \\
\hline \multirow{2}{*}{ Scheme I } & 1 layer & 1.29 & 1.17 & 1.33 & 1.06 & 1.03 & \\
\hline & 2 layers & 1.68 & 1.82 & 1.20 & 2.18 & 1.67 & \\
\hline \multirow{2}{*}{ Scheme II } & 1 layer & 1.38 & 1.49 & 1.45 & / & / & \\
\hline & 2 layers & 1.71 & 1.69 & 1.62 & / & / & \\
\hline
\end{tabular}
peak strain for one and two layers respectively. For cylinders from Scheme II, the ultimate axial strain increased by $45 \%$ and $62 \%$.

DIC was not used for four unconfined cylinders: C1_WUn, C4_WUn, C1_CUn and C2_CUn. It should be noted that DIC results are reliable up to the peak load; after that point, local cracks occurred and strains are not anymore representative of the global behaviour of the cylinders. The average axial strains at peak for confined cylinders measured with DIC, were lower than those measured with the transducers by a value between $12 \%$ and $33 \%$. All the axial and hoop stress-strain curves from DIC are plotted in Fig. 7 and Fig. 8, for Scheme I and Scheme II cylinders respectively and together in Fig. 9 for ease of comparison. The plots show a similar initial slope of all confined and unconfined specimens. This is likely due to strains being measured in a more consistent way in the middle half of cylinders and averaged over a considerable number of virtual strain gauges. 
237 Regarding hoop strains, the ratio between hoop and axial strain at peak was 1.15 for unconfined Scheme I cylinders, 238 reducing to 1.07 for cylinders confined with one layer and further down to 0.86 for cylinders confined with two layers.

239 Similarly, for Scheme II cylinders the ratio was 1.02 for cylinders confined with one layer and 0.86 for cylinders

240 confined by two layers. As for the strength increments these values show that one BFRP layer was more effective on 241 the weakest masonry (Scheme II) while two layers had a similar effect. The hoop strain of Scheme I cylinders with one

242 BFRP wrap also increased slightely compared to unconfined cylinders (3\%), while for cylinders confined by two layers the increment at peak was significantly larger (67\%). 

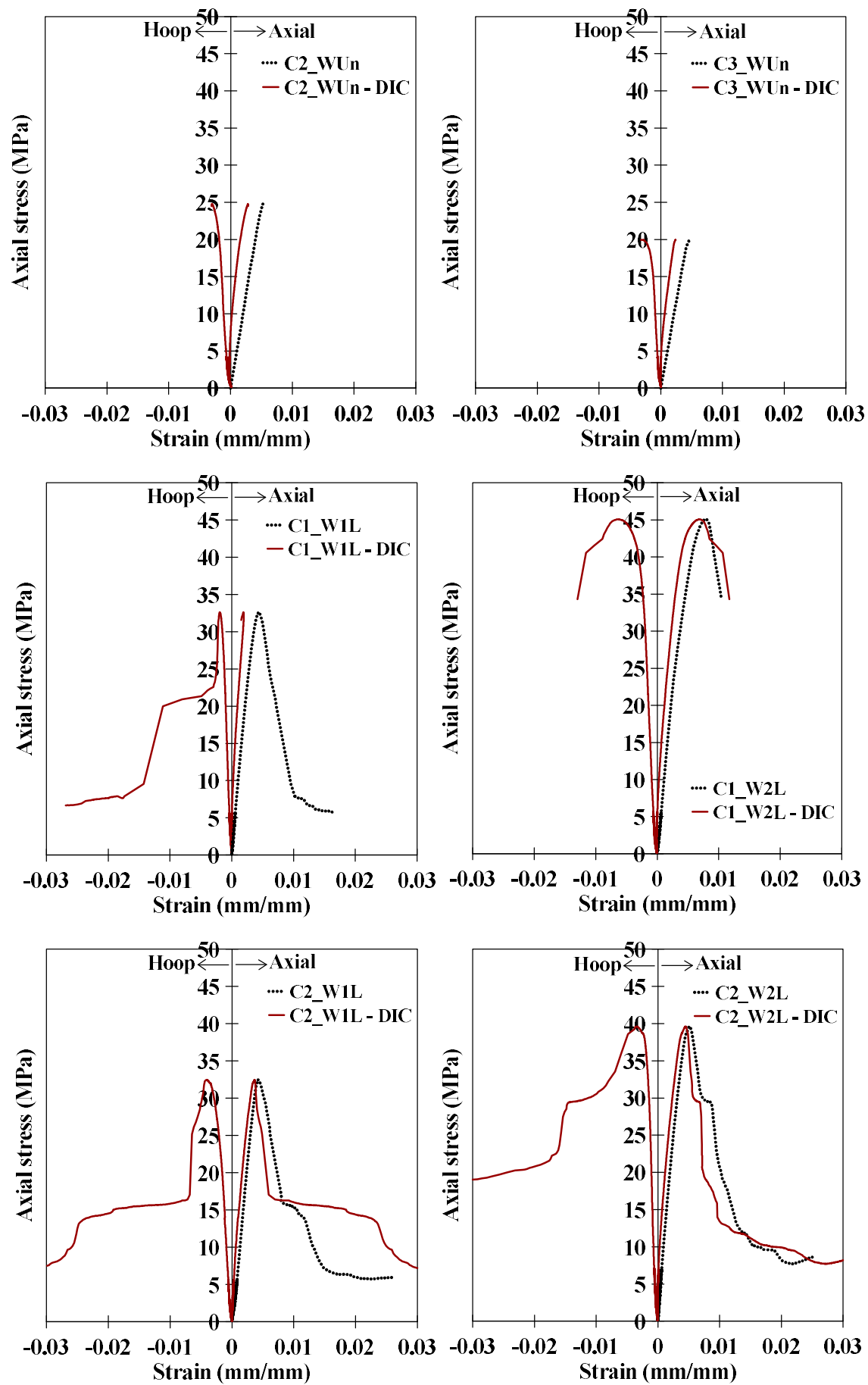

Fig. 7 Stress-strain curves in the axial and the hoop directions for Scheme I cylinders (DIC and LVDTs measurements). 

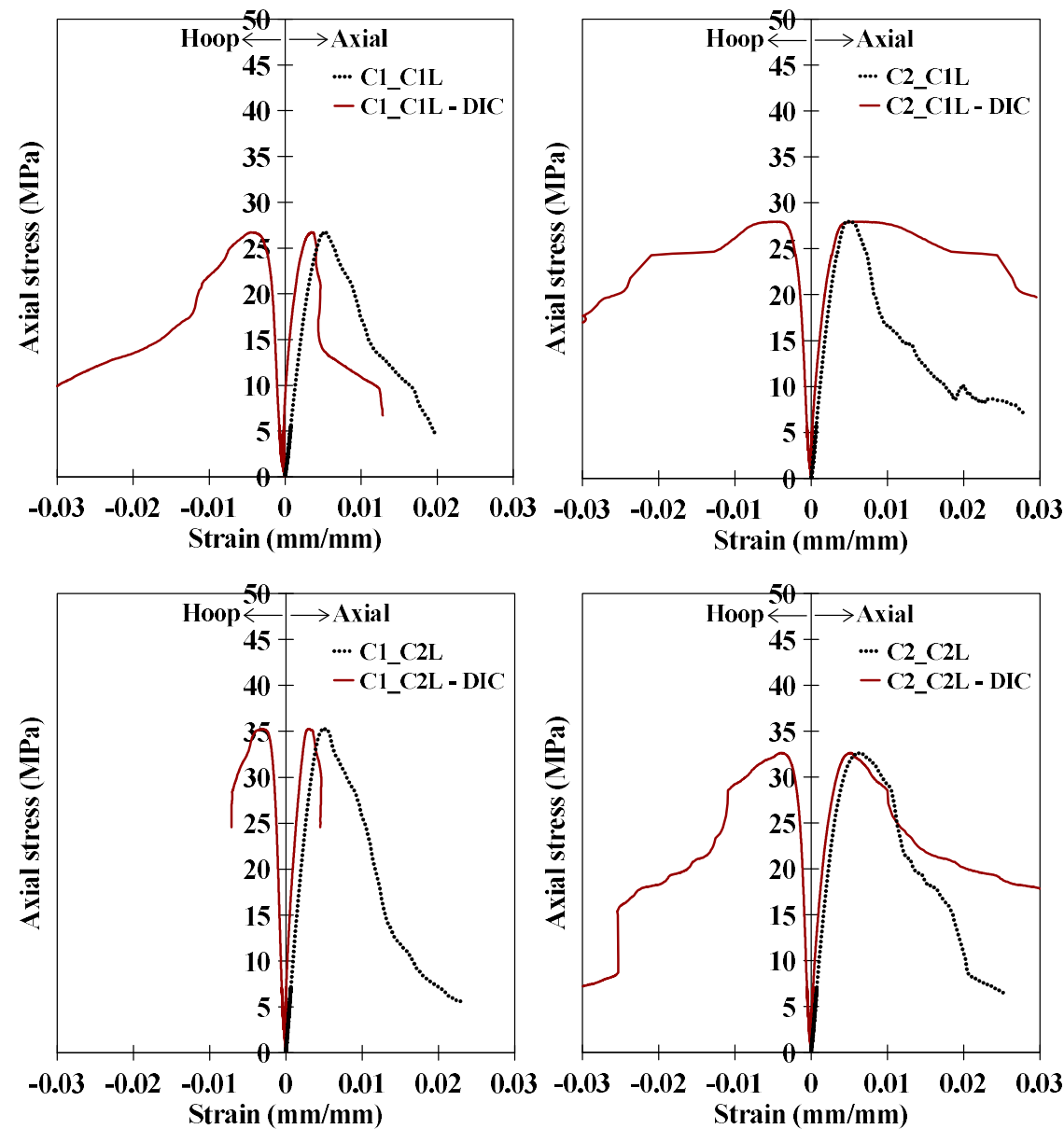

Fig. 8 Stress-strain curves in the axial and the hoop directions for Scheme II (DIC and LVDTs measurements).
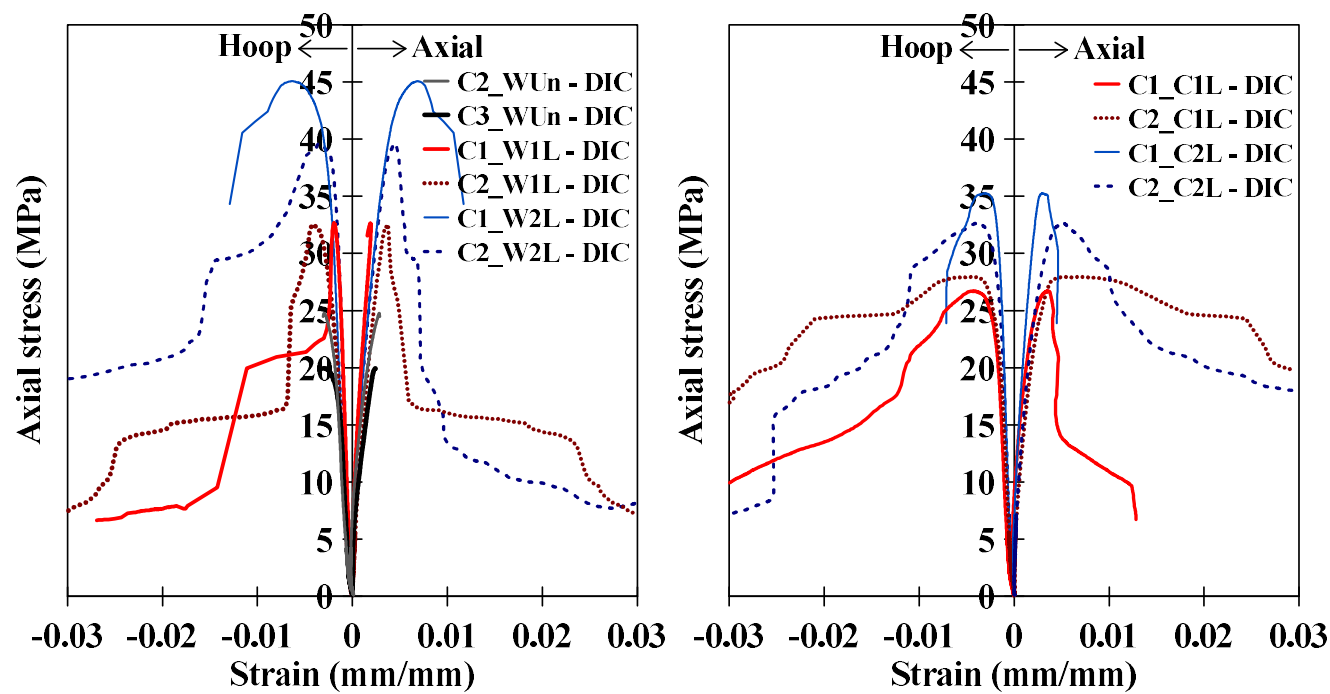

Fig. 9 Stress-strain curves in the axial and hoop direction using DIC: a) Scheme I; b) Scheme II

\section{Failure modes}

Fig. 10 shows the failure modes of confined and unconfined cylinders at the end of the compression tests. The 
almost vertical cracks along the height of the specimens. There were not evident differences in the failure mode of Scheme I and II. In general, vertical joints created preferential routes for the development of cracks, which propagated at the interface between bricks and mortar joints. This was more evident for Scheme II involving three joints than for Scheme I where cracks developed also in bricks. At failure, due to the cracks, large portion of bricks between mortar joints were completely detached from the cylinders.

The confined cylinders all failed for the tensile rupture of the BFRP jacket. These specimens were characterized by two or more almost vertical cracks connected horizontally near a horizontal mortar joint. Local bulging was also visible and crushed masonry could be observed at the end of the test inside the jackets.

There were not considerable differences in the failure mode of cylinders wrapped with one or two BFRP layers.
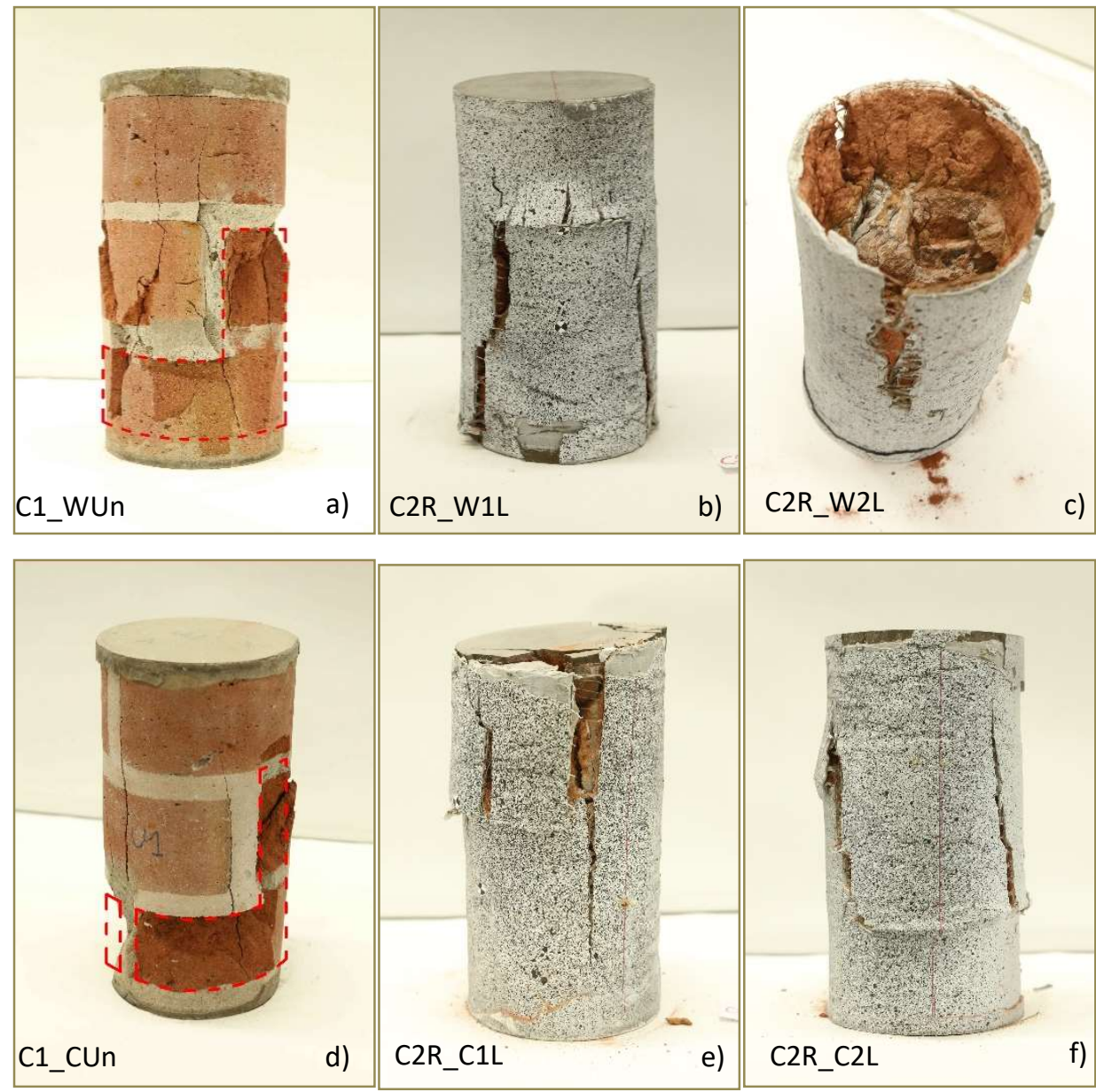

Fig. 10 Cylinder failure modes: a) Scheme I unconfined; b) Scheme I, 1 layer; c) Scheme I, 2 layers; d) Scheme II unconfined; e) Scheme II-1 layer; f) Scheme II-2 layers 
In this section the experimental data collected has been compared to the prediction given by analytical models in the literature. Different approaches are adopted, evaluating the reliability of currently available formulations to predict the behaviour of BFRP confined masonry.

\section{Confined strength}

274

275

Five analytical models are considered: Campione and Miraglia (2003) [12], (C\&M), Krevaikas and Triantafillou (2005) [10] (KRE), Corradi et al. (2007) [11] (CO), Di Ludovico et al. (2010) [8] (DIL) and the Italian CNR-DT 200/2013 Guidelines [15] (CNR). The effective confinement pressure was calculated by the well known rigid body equilibrium of the section:

$\mathrm{f}_{\mathrm{l}}=\frac{2 \mathrm{t}_{\mathrm{f}} \mathrm{f}_{\mathrm{r}}}{\mathrm{D}}$

where $t_{\mathrm{f}}$ is the grid equivalent thickness and $\mathrm{D}$ is the cylinder diameter. In all the above models, except the CNR, the stress in the fabric $f_{r}$ is calculated based on the maximum strain at failure:

$$
f_{r}=\varepsilon_{f u} E_{f}
$$

being $\varepsilon_{\mathrm{fu}}$ its ultimate tensile strain and $\mathrm{E}_{\mathrm{f}}$ the elastic modulus.

In the CNR model a reduced maximum strain, $\varepsilon_{\mathrm{fd} \text {,rid }}$ in the composite is used con calculating $\mathrm{f}_{\mathrm{r}}$ :

$$
\mathrm{f}_{\mathrm{r}}=\varepsilon_{\mathrm{fd}, \mathrm{rid}} \mathrm{E}_{\mathrm{f}}
$$

$\varepsilon_{\mathrm{fd}, \text { rid }}$ being a function of the environmental conversion factor $\eta \mathrm{a}$, the characteristic value of the ultimate tensile strain of the FRP $\varepsilon_{\mathrm{fk}}$ and the partial safety factor $\gamma_{\mathrm{f}}$.

$$
\varepsilon_{f d, r i d}=\min \left\{\eta_{a} \cdot \varepsilon_{f k} / \gamma_{f} ; 0.004\right\}
$$

The CNR model has also been evaluated using the same confinement pressure equation used for the other models (see Eq. 2) and is indicated by $\mathrm{CNR}_{\text {mod }}$ in the following.

The expressions for calculating the compressive strength of FRP-confined masonry $\mathrm{f}_{\mathrm{mc}}$ as a function of the effective confinement pressure $\mathrm{f}_{\mathrm{l}}^{\prime}$ and unconfined masonry strength $\mathrm{f}_{\mathrm{m} 0}$ are reported on Table 6. 


\section{Confined strain and stress-strain curves}

The strain at peak stress of BFRP-reinforced specimens was evaluated taken into account three models proposed by Campione and Miraglia (2003) [12] (C\&M), Krevaikas and Triantafillou (2005) [10] (KRE), Cascardi et al. (2017) [27] (CAS). Table 7 presents the used formulations. Moreover, a modification of the equation provided by Krevaikas and Triantafillou (2005) is here proposed, in which the coefficient $\mathrm{k}_{2}$ is modified adopting the value 0.015 instead of the value 0.034 proposed by the authors (indicated by $\mathrm{KRE}_{\text {mod }}$ in the following).

The full stress/strain curves for BFRP-confined cylinders is obtained by adopting the constitutive law proposed by La Mendola and Papia (2002) [28] for calcarenite masonry members:

$$
\begin{gathered}
\frac{\sigma}{f_{m c}}=\frac{A \cdot \bar{\varepsilon}+(U+1) \cdot \bar{\varepsilon}^{2}}{1+(A-2) \cdot \bar{\varepsilon}+U \cdot \bar{\varepsilon}^{2}} \\
\bar{\varepsilon}=\frac{\varepsilon}{\varepsilon_{m c}} ; \quad A=\frac{E_{m 0}}{E_{\mathrm{sec}}^{*}} ; \quad E_{\mathrm{sec}}^{*}=\frac{f_{m c}}{\varepsilon_{m c}}
\end{gathered}
$$

where $\mathrm{f}_{\mathrm{mc}}$ and $\varepsilon_{\mathrm{mc}}$ are respectively the strength and the corresponding strain of FRP-confined masonry, $\mathrm{E}_{\mathrm{m} 0}$ is the Young's modulus of unconfined masonry and $U$ is a parameter which rules the slope of the softening branch. Here two values of $U$ are proposed, equal to 0.75 and 1 for Scheme I and Scheme II respectively, in order to fit the post-peak behaviour of cylinders from the two schemes.

For these curves the strain at peak stress $\varepsilon_{m c}$ is evaluated using the modified model of Krevaikas and Triantafillou (2005) $\left(\mathrm{k}_{2}=0.015\right)$ while for the strength the modifed $\mathrm{CNR}_{\text {mod }}$ value was used. 
Table 6: Analytical models for compressive strength of FRP-confined masonry

\begin{tabular}{|c|c|}
\hline Model & Compressive strength of FRP-confined masonry \\
\hline $\begin{array}{l}\text { Campione and Miraglia, } \\
2003 \text { (C\&M) }\end{array}$ & $\begin{array}{l}f_{m c}=f_{m 0}+k_{1} \cdot f_{l}^{\prime} \\
k_{1}=2\end{array}$ \\
\hline $\begin{array}{l}\text { Krevaikas and } \\
\text { Triantafillou, } 2005 \text { (KRE) }\end{array}$ & $\begin{cases}f_{m c}=f_{m 0} & \text { if } \frac{f_{l}^{\prime}}{f_{m 0}} \leq 0.24 \\
f_{m c}=f_{m 0} \cdot\left(0.6+1.65 \cdot \frac{f_{l}^{\prime}}{f_{m 0}}\right) & \text { if } \frac{f_{l}^{\prime}}{f_{m 0}} \geq 0.24\end{cases}$ \\
\hline $\begin{array}{l}\text { Corradi et al., } 2007 \\
\text { (CO) }\end{array}$ & $\begin{array}{l}f_{m c}=f_{m 0}+k_{1} \cdot f_{l}^{\prime} \\
k_{1}=2.4 \cdot\left(\frac{f_{l}^{\prime}}{f_{m 0}}\right)^{-0.17}\end{array}$ \\
\hline $\begin{array}{l}\text { Di Ludovico et al., } 2010 \\
\text { (DIL) }\end{array}$ & $\begin{array}{l}f_{m c}=f_{m 0}+k_{1} \cdot f_{l}^{\prime} \\
k_{1}=1.53 \cdot\left(\frac{f_{l}^{\prime}}{f_{m 0}}\right)^{-0.10}\end{array}$ \\
\hline CNR-DT 200/2013, (CNR) & $\begin{array}{l}f_{m c}=f_{m 0}+k_{1} \cdot\left(\frac{f_{l}^{\prime}}{f_{m 0}}\right)^{\alpha_{1}} \text { where } \alpha_{1}=0.5 \\
k_{1}=\alpha_{2} \cdot\left(\frac{g_{m}}{1000}\right)^{\alpha_{3}} \text { where } \\
g_{m}: \text { mass density of masonry } \\
\alpha_{2}=\alpha_{3}=1\end{array}$ \\
\hline
\end{tabular}

Table 7: Analytical models for strain at peak stress of FRP-confined masonry

\begin{tabular}{ll}
\hline Model & Strain at peak stress of FRP-confined masonry \\
\hline Campione and Miraglia, 2003 & $\frac{\varepsilon_{m c}}{\varepsilon_{m 0}}=1+\rho_{f} \cdot \frac{1}{\varepsilon_{m 0}} \cdot \frac{f_{r}^{2}}{E_{f}} \cdot \frac{1}{f_{m 0}+k_{e} \cdot f_{l}}$ \\
(C\&M) & where $\quad \rho_{f}=\frac{2 \cdot\left[2 \cdot\left(b-2 r_{c}\right)+\pi r_{c}\right] \cdot t_{f}}{b^{2}-4 \cdot\left[r_{c}^{2}-\left(\pi r_{c}^{2} / 4\right)\right]}$ \\
\hline Krevaikas and Triantafillou, 2005 & $\frac{\varepsilon_{m c}}{\varepsilon_{m 0}}=1+\frac{k_{2}}{\varepsilon_{m 0}} \cdot \frac{f_{l}^{\prime}}{f_{m 0}} \quad$ where $k_{2}=0.034$ \\
(KRE) & $\frac{\varepsilon_{m c}}{\varepsilon_{m 0}}=1+\left(\frac{f_{l}}{f_{m 0}}\right)^{0.5}$ \\
\hline Cascardi et al., 2017 & \\
(CAS) &
\end{tabular}

The experimental/analytical comparisons of strength and peak strain for the BFRP confined cylinders values are 
unconfined masonry strength $\mathrm{f}_{\mathrm{l}}^{\prime} / \mathrm{f}_{\mathrm{m} 0}$. For each model the relative error (RE) is also reported. The best performing models are printed in bold.

Among the models available in the literature Corradi et al. (2007) (CO) provides the lowest relative error. The model slightely underestimates the confined strength by $-5 \%$ at most for cylinders confined by one layers and by $-14 \%$ for cylinders confined with two layers. The modified CNR model $\left(\mathrm{CNR}_{\bmod }\right)$ provides the best estimates for cylinders confined by two layers (maximum relative error $-3 \%$ ). The other models all underestimate the confined strength by values up to $-42 \%$ with the maximum errors occurring for cylinders confined by two BFRP layers. A graphical representation of the strength model prediction is given in Fig. 11.

Table 8: Confined strength increment: experimental values vs model predictions

\begin{tabular}{|c|c|c|c|c|c|c|c|c|c|c|}
\hline & \multirow[b]{2}{*}{ Specimen } & \multirow{2}{*}{$\begin{array}{l}\operatorname{Exp} \\
\left(f_{m c} / f_{m 0}\right)\end{array}$} & C\&M & KRE & $\mathrm{CO}$ & DIL & CNRmod & \multirow[b]{2}{*}{$\left(f^{\prime}, / f_{m 0}\right)$} & CNR & \multirow[b]{2}{*}{$\left(f^{\prime}, / f_{m 0}\right)$} \\
\hline & & & \multicolumn{5}{|c|}{$\left(f_{m c} / f_{m 0}\right)$} & & $\begin{array}{l}\left(f_{m c} / f_{m 0}\right) \\
(R E)\end{array}$ & \\
\hline \multirow{4}{*}{ Scheme I } & C1R_W1L & \multirow{2}{*}{1.29} & 1.13 & 1 & 1.26 & 1.13 & 1.44 & \multirow{2}{*}{0.070} & 1.18 & \multirow{2}{*}{0.011} \\
\hline & C2R_W1L & & $-(12 \%)$ & $-(23 \%)$ & $-(3 \%)$ & $-(12 \%)$ & $(12 \%)$ & & $(-9 \%)$ & \\
\hline & C1R_W2L & \multirow{2}{*}{1.68} & 1.27 & 1 & 1.45 & 1.25 & 1.63 & \multirow{2}{*}{0.130} & 1.25 & \multirow{2}{*}{0.022} \\
\hline & C2R_W2L & & $-(25 \%)$ & $-(41 \%)$ & $-(13 \%)$ & $-(26 \%)$ & $-(3 \%)$ & & $(-26 \%)$ & \\
\hline \multirow{4}{*}{ Scheme II } & C1R_C1L & \multirow{2}{*}{1.38} & 1.17 & 1 & 1.31 & 1.17 & 1.50 & \multirow{2}{*}{0.090} & 1.20 & \multirow{2}{*}{0.014} \\
\hline & C2R_C1L & & $-(15 \%)$ & $-(27 \%)$ & $-(5 \%)$ & $-(15 \%)$ & (9\%) & & $(-13 \%)$ & \\
\hline & C1R_C2L & \multirow{2}{*}{1.71} & 1.34 & 1 & 1.55 & 1.31 & 1.71 & \multirow{2}{*}{0.170} & 1.28 & \multirow{2}{*}{0.027} \\
\hline & C2R_C2L & & $-(22 \%)$ & $-(42 \%)$ & $-(9 \%)$ & $-(23 \%)$ & $(0 \%)$ & & $(-25 \%)$ & \\
\hline
\end{tabular}



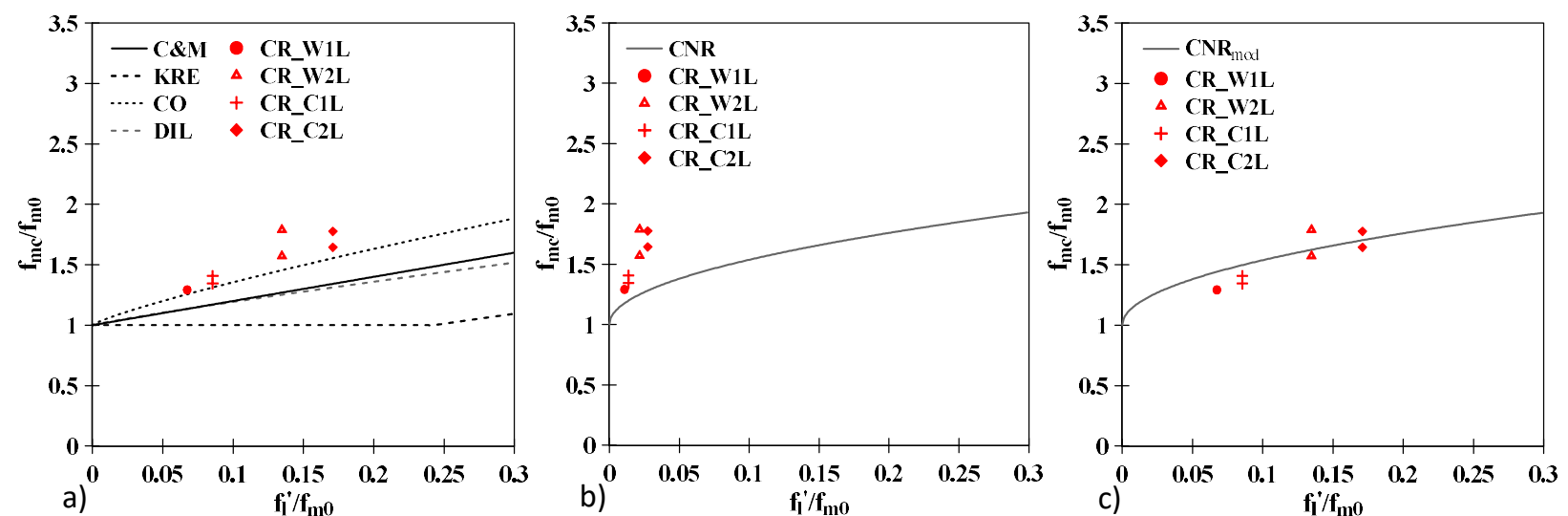

Fig. 11 Compressive strength increase as a function of normalized effective confinement pressure for BFRP-confined cylinders: a) C\&M, KRE, CO, DIL; b) CNR; and c) $\mathrm{CNR}_{\text {mod }}$

A comparison between theoretical and experimental strain at peak values of confined cylinder is reported in Table 9.

Among the models already available in the literature Cascardi et al. (2017) provides the best estimates of the strain

(maximum error equal to $-14 \%$ for one BFRP layers and $-17 \%$ for two layers). The modified Krevaikas and Triantafillou

(2005) model $\left(\mathrm{KRE}_{\text {mod }}\right)$ also gives very good estimates with maximum relative error for cyinders with two layers equal to $-8 \%$.

Table 9: Strain at peak stress of confined cylinders: experimental values vs model predictions

\begin{tabular}{|c|c|c|c|c|c|c|}
\hline & & Exp & C\&M & KRE & CAS & $K R E_{\text {mod }}$ \\
\hline & Specimen & $\varepsilon_{\mathrm{mc}}$ & $\begin{array}{l}\varepsilon_{\mathrm{mc}} \\
\text { (RE=rel }\end{array}$ & tive error & & \\
\hline \multirow{4}{*}{ Scheme I } & C1R_W1L & \multirow{2}{*}{0.0042} & 0.0072 & 0.0063 & 0.0050 & 0.0050 \\
\hline & C2R_W1L & & (71\%) & (50\%) & $(19 \%)$ & $(19 \%)$ \\
\hline & C1R_W2L & \multirow{2}{*}{0.0065} & 0.0099 & 0.0086 & 0.0055 & 0.0060 \\
\hline & C2R_W2L & & $(52 \%)$ & $(32 \%)$ & $-(15 \%)$ & $-(7 \%)$ \\
\hline \multirow{4}{*}{ Scheme II } & C1R_C1L & \multirow{2}{*}{0.0051} & 0.0073 & 0.0063 & 0.0044 & 0.0047 \\
\hline & C2R_C1L & & $(43 \%)$ & $(24 \%)$ & $-(14 \%)$ & $-(8 \%)$ \\
\hline & C1R_C2L & \multirow{2}{*}{0.0058} & & & & \\
\hline & C2R_C2L & & (84\%) & (59\%) & $-(17 \%)$ & $(3 \%)$ \\
\hline
\end{tabular}

The stress-strain results obtained from the analytical model are plotted in Fig. 12 . The adopted model is able to predict the average compressive response in terms of peak stress, corresponding strain and slope of ascending and softening branches. The compressive strength of BFRP confined masonry is predicted with enough accuracy, although predictions slightly overestimate the average values of experimental data in the case of one-layer reinforced specimens. In particular, percentage differences between the average experimental values of compressive strength 

and experimental average strength values.
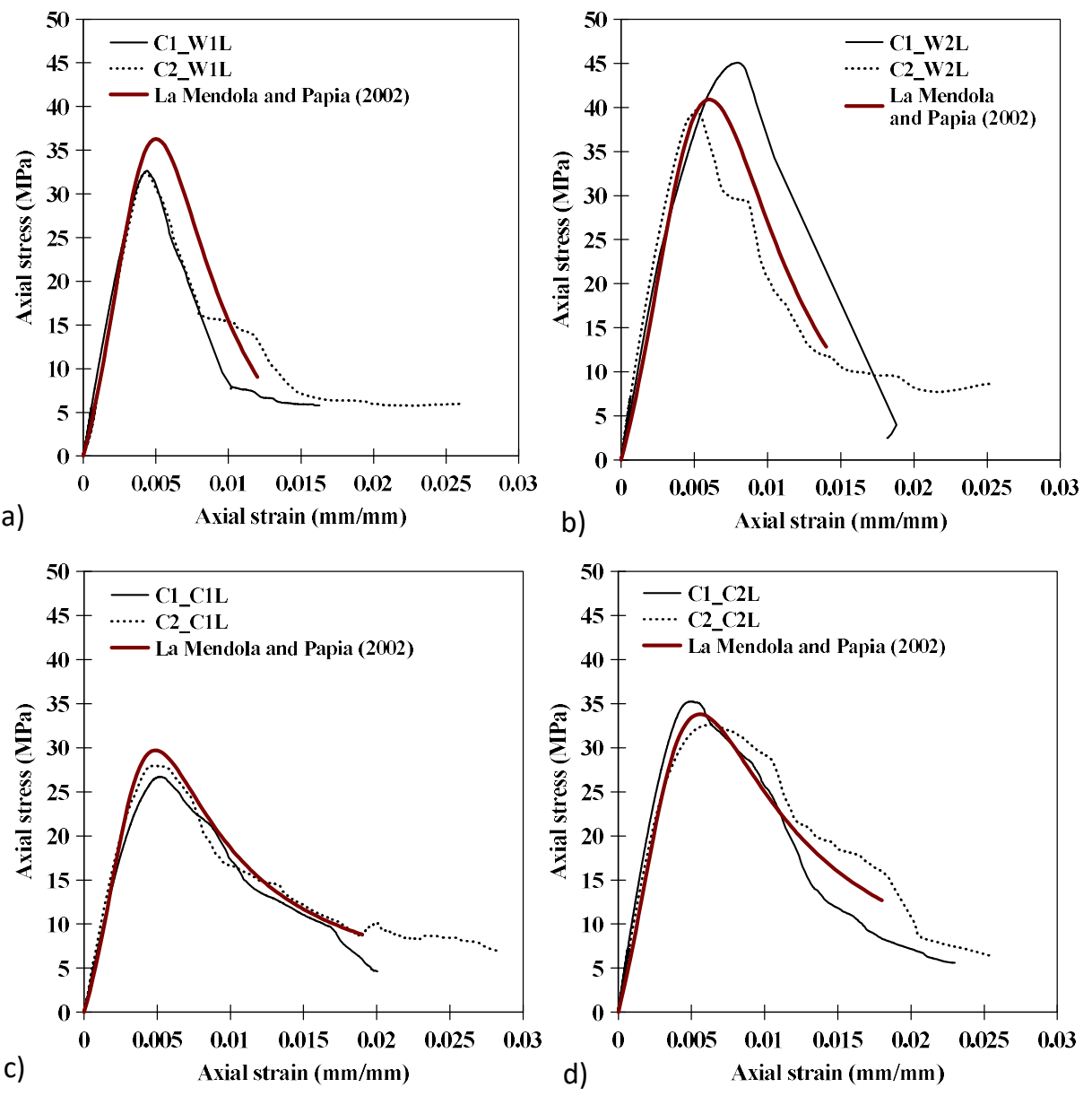

Fig. 12 Comparison between experimental and analytical compressive response of BFRP-confined cylinders:

a) Scheme I and one layer; b) Scheme I and two layers; c) Scheme II and one layer; d) Scheme II and two layers

\section{Conclusions}

Based on the experimental and analytical analyses in the previous sections the following conclusions can be drawn: compared to cylinders with one vertical joint only (Scheme I);

- $\quad$ BFRP wrapped cylinders failed by tensile rupture of the BFRP jacket. No debonding at the overlapping zone was observed. The inner masonry core of wrapped cylinders was crushed at failure; 
- $\quad$ The BFRP composite significantly increased the strength of the confined cylinders: Increaments of $29 \%$ and $38 \%$ were observed for one-layer confined cylinders and $68 \%$ and $71 \%$ for two-layer confined cylinders (Scheme I and II respectively).

\section{Acknowledgement}




\section{References}

1. Fiore V Scalici T, Di Bella G, Valenza A. A review on basalt fibre and its composites. Compos Part B-Eng. 20151 June 2015;74:74-94.

2. Campione G, La Mendola L, Monaco A, Valenza A, Fiore V. Behavior in compression of concrete cylinders externally wrapped with basalt fibers. Compos Part B-Eng. 2015;69:576-86

3. Ouyang L, Gao W, Zhen B, Lu Z. Seismic retrofit of square reinforced concrete columns using basalt and carbon fiber-reinforced polymer sheets: A comparative study. Compos Struct. 2017;162:294-307.

4. Sadeghian P, Fillmore B. Strain Distribution of Basalt FRP-Wrapped Concrete Cylinders. Case Studies in Construction Materials. 2018; https://doi.org/10.1016/j.cscm.2018.e00171.

5. Huang J, Li T, Zhu D, Gao P, Zhou A. Compressive behaviour of circular and square concrete columns externally confined by different types of basalt fiber-reinforced palymer. Adv Struct Eng. 2020;1-14. 2020;14:8.

6. Baasankhuu B,Choi D, Ha S. Behavior of small-scale concrete cylinders in compression laterally confined by basalt fiber and PEN fiber reinforced polymer composites. Int J Concr Structs M. 2020;14:8.

7. Suon S, Saleem S, Pimanmas A. Compressive behavior of basalt FRP-confined circular and non-circular concrete specimens. Constr Build Mater. 2019;195:85-103.

8. Di Ludovico M, D'Ambra C, Prota A, Manfredi G. FRP confinement of tuff and clay brick columns: experimental study and assessment of analytical models. J Compos Constr. 2010;14(5):583-96.

9. Micelli F, Angiuli R, Corvaglia P, Aiello MA. Passive and SMA-activated confinement of circular masonry columns with basalt and glass fibers composites. Compos Part B-Eng. 2014;67:348-62.

10. Krevaikas TD, Triantafillou TC. Masonry confinement with fiber-reinforced polymers. J Compos Constr. 2005;9(2):128-35.

11. Corradi M, Grazini A, Borri A. Confinement of brick masonry columns with CFRP materials. Compos Sci Technol. 2007;67(9):1772-83.

12. Campione G, Miraglia N. Strength and strain capacities of concrete compression members reinforced with FRP. Cement Concrete Comp. 2003;25(1):31-41.

13. Faella C, Martinelli E, Camorani G, Aiello MA, Micelli F, Nigro E. Masonry columns confined by composite materials: Design formulae. Compos Part B-Eng. 2011;42(4):705-16.

14. Lignola GP, Angiuli R, Prota A, Aiello MA. FRP confinement of masonry: analytical modeling. Mater Struct. 2014;47(12):2101-15.

15. Italian Council of Research (CNR). CNR-DT 200 Guide for the design and construction of externally bonded FRP systems for strengthening existing structures. 2013.

16. Minafò G, D'Anna J, Cucchiara C, Monaco A, La Mendola L. Analytical stress-strain law of FRP confined masonry in compression: Literature review and design provisions. Compos Part B-Eng. 2017;115:160-9.

17. Micelli F, Angiuli R, Corvaglia P, Aiello MA. Passive and SMA-activated confinement of circular masonry columns with basalt and glass fibers composites. Composites Part B: Engineering. 2014 Dec 1;67:34862. 
18. Aiello MA, Micelli F, Valente L. Structural upgrading of masonry columns by using composite reinforcements. Journal of Composites for Construction. 2007 Dec;11(6):650-8.

19. Alecci V, Bati SB, Ranocchiai G. Study of brick masonry columns confined with CFRP composite. Journal of Composites for Construction. 2009 Jun;13(3):179-87.

20. Chen J.F., Ai J. and Stratford T.J. Effect of geometric discontinuities on strains in FRP wrapped columns. J Compos Constr. 2010; 14(2): 136-145.

21. Chen J.F., Li, S.Q. and Bisby L.A. Factors affecting the ultimate condition of FRP-wrapped concrete columns. J Compos Constr. 2013; 17(1): 67-78.

22. EN 772-1 Method of test for masonry units - Part 1: Determination of compressive strength. 2011.

23. EN 1015-11 Methods of test for mortar for masonry - Part 11: Determination of flexural and compressive strength of hardened mortar. 1999.

24. ISO 13934-1 Textiles - Tensile properties of fabrics - Part 1: Determination of maximum force and elongation at maximum force using the strip method. 2013.

25. GOM GmbH. GOM testing-technical documentation as of V8 SR1 digital image correlation and strain computation basics. 2016.

26. Bisby L, Chen J, Li S, Stratford T, Cueva N, Crossling K. Strengthening fire-damaged concrete by confinement with fibre-reinforced polymer wraps. Eng Struct. 2011;33(12):3381-91.

27. Cascardi A, Aiello MA, Triantafillou T. Analysis-oriented model for concrete and masonry confined with fiber reinforced mortar. Mater Struct. 2017;50(4):202.

28. La Mendola, L. and Papia, M. General stress-strain model for concrete or masonry response under uniaxial cyclic compression. Struct Eng Mech. 2002;14(4):435-454. 